\title{
Diglosia Bahasa Arab Pesantren dan Upaya Pemertahanan Bahasa Daerah
}

\author{
Wahyu Hanafi 1 \\ Email; wahyuhanafi89@gmail.com
}

\begin{abstract}
The purpose of this study is to describe the diglossia of Arabic pesantren and its influence on regional language defense, as well as providing a resolution to the pesantren in maintaining the regional language. The research method used is descriptive qualitative. The result of this research is that the existence of diglossia Arabic pesantren which is done consistently can influence the defense of local language of speech in pesantren. The solution for pesantren in maintaining the regional languages is to establish a language center, reschedule language activities, hold language festivals, give appreciation and cultivate a sense of pride towards its speakers.
\end{abstract}

Keywords: Diglossia, Arabic Language, Pesantren, Regional Language

\section{PENDAHULUAN}

Tuntutan penguasan bahasa asing (B2) di era milenial bagi masyarakat merupakan salah satu bentuk kemajuan berbahasa. Berbagai macam faktor seperti sosial, ekonomi, dan budaya turut melatarbelakangi timbulnya pembelajaran B2. Akan tetapi, faktor politik adalah faktor yang paling dominan dalam timbulnya pembelajaran B2 sehingga mampu mengubah masyarakat menjadi masyarakat bilingual. Pergulatan demi mendapatkan posisi yang sentral dan strategis dalam mempertahankan eksistensi bahasa akan membawa pembelajaran B2 merambah pada berbagai wilayah, mulai dari lembaga publik,

1 Dosen Tetap Tarbiyah Institut Agama Islam Sunan Giri Ponorogo 
pendidikan formal dan non-formal yang salah satunya adalah memasuki lembaga pesantren.

Para linguis Indonesia mendeklarasikan bahwa bahasa asing yang paling banyak diminati oleh masyarakat Indonesia adalah bahasa Inggris dan bahasa Arab. Pesatnya lembaga-lembaga pendidikan bahasa Inggris karena bahasa ini mampu merambah pada seluruh aspek semisal bidang ilmu pengetahuan, sosial, budaya, politik, hukum, dan teknologi. Dalam pandangan filsafat bahasa, bahasa Inggris mempunyai nilai register dan hierarki yang cukup tinggi. Eksistensi bahasa Arab menduduki posisi kedua setelah bahasa Inggris meskipun keberadaan bahasa Arab sudah masuk terlebih dahulu di Indonesia semenjak datangnya Islam. Secara historis, babak awal masuknya bahasa Inggris dan Arab ke lembaga pesantren adalah mereaktualisasikan pengetahuan umum dan sebagai pengantar studi Islam. Setelah berjalan dalam beberapa dekade yang cukup panjang, tujuan pembelajaran bahasa Inggris dan Arab di pesantren mulai direkonstruksi. Kedua bahasa asing tersebut dipelajari tidak hanya dengan urgensi dan reaktualisasi pengantar pengetahuan umum dan studi Islam, akan tetapi dengan tujuan membentuk masyarakat tutur pesantren yang mampu dan cakap dalam berdiplomatik di kancah Internasional yang menggunakan bahasa Inggris dan Arab.

Masyarakat tutur yang berdomisili di lembaga pesantren bersifat heterogen yang membawa bahasa daerah masing-masing. Sebagai masyarakat yang menghargai hasil produk budaya yaitu bahasa, mereka berkewajiban untuk memelihara dan mempertahankan bahasa daerah tersebut dimanapun mereka tinggal. Pembelajaran bahasa Arab di pesantren dengan berbagai macam pendekatan, metode dan modelnya, akan membawa diglosia. Peran diglosia bahasa Arab pesantren secara perlahan akan mengikis keberadaan bahasa daerah (B1) yang dibawa oleh masing-masing masyarakat tutur pesantren. Selain itu, kebijakan pesantren yang mewajibkan berbahasa Arab dalam segala hal juga turut mengikis eksistensi bahasa daerah. Menurut peneliti, kebijakan tersebut mempunyai sisi positif dan negatif. Sisi negatif yang melahirkan generasi masyarakat tutur pesantren yang lupa dalam bahasa daerah adalah langkah yang harus dikritisi. Lantas, bagaiaman wacana ini mampu mendialogkan antara pembelajaran B2 di pesantren dan pemertahanan B1? 


\section{PEMBAHASAN}

\section{Diglosia dalam Terminologi Sosiologi Bahasa; Ruang Ontologi dan Epistemologi.}

Menurut Ferguson, terminologi diglosia diistilahkan dengan situasi yang di dalamnya ada dua ragam dari satu bahasa hidup berdampingan dengan peran masing-masing dalam masyarakat itu,2 atau bisa disebut dengan suatu situasi bahasa di mana terdapat pembagian fungsional atas variasi-variasi bahasa atau bahasa-bahasa yang ada di masyarakat. Diglosia merupakan situasi pemakaian bahasa yang stabil karena setiap bahasa diberi keleluasaan dalam menjalankan fungsi kemasyarakatannya secara proposional.z Dalam arti yang lebih luas, ragam komunikasi verbal dan non verbal masyarakat tutur bisa menggunakan bahasa yang bersifat formal, informal dan nonformal, baku dan non baku yang berdasarkan fungsi dan hierarki kelas penutur bahasa. Kunci pokok dalam diglosia adalah adanya fungsi dalam bahasa itu.

Terma diglosia merupakan salah satu bahasan dalam disiplin ilmu Sosiolinguistik. Dalam keberlangsungan hidup di masyarakat, bahasa mempunyai peran yang paling penting dalam fungsi komunikasi. Dengan adanya bahasa, kontak interaksi masyarakat akan menjadi lebih mudah dan dimengerti oleh masing-masing penutur dan mitra tutur. Dalam masyarakat atau komunitas multilingual itu terdapat kode-kode kebahasaan tertentu yang diperankan sebagai bahasa tinggi, tetapi ada kode-kode tertentu yang diperan fungsikan sebagai bahasa rendah. Pada masyarakat multilingual, yang di dalamnya terdapat pembedaan peran dan fungsi yang cukup jelas atas ragamragam atau kode-kode bahasa yang dimilikinya dengan sendirinya membentuk situasi diglosik atau diglosia. Masyarakat atau komunitas tuturnya sendiri disebut dengan masyarakat diglosik atau diglosia. Salah satu kenyataan yang tidak dapat dipungkiri di dalam komunitas multilingual yang berfakta diglosia adalah selalu bergesernya kode-kode kebahasaan yang digunakan oleh setiap warga masyarakat atau komunitasnya. Jadi, pergeseran kode-kode kebahasaan itu tidak selalu terjadi dalam sosok bahasa yang berciri

\footnotetext{
$\overline{2}$ Sumarsono, Sosiolinguistik, (Yogyakarta: Pustaka Pelajar, 2017), hlm. 191.

I Dewa Putu Wijana \& M. Rohmadi, Sosiolinguistik: Kajian Teori dan Analisis, (Yogyakarta: Pustaka Pelajar, 2013), hlm. 34.
} 
makro, tetapi bisa pula pada aspek-aspek kecil dari entitas kebahasaan tertentu.4

Kemudian Ferguson menjelaskan diglosia itu dari beberapa segi; fungsi, prestise, warisan tradisi tulis-menulis, pemerolehan, pembakuan, tata bahasa, dan fonologi. Menurutnya, "fungsi” adalah kiriteria yang paling tinggi dalam diglosia. Dalam suatu bahasa ada dua ragam yang berbeda. Yang satu disebut dialek atas $(=A)$ atau High Dialect $(=H)$ dan dialek bawah $(=B)$ atau Low Dialect. Dalam bahasa Arab, $H$ mengacu kepada bahasa Arab yang dipakai dalam al-Qur'an (kitab suci) sedangkan $L$ mengacu kepada ragam bahasa Arab yang dipakai masyarakat Arab di berbagai negara. 5

Kedua, segi "prestise” sikap penutur dalam guyup diglosia bahwa $H$ itu superior (unggul), lebih gagah dan lebih nalar (logis). Ragam $L$ dianggap lebih rendah (inferior), bahkan keberadaanya cenderung dihindari. Sikap-sikap semacam itu juga diakui penutur yang tidak mengerti $H_{.6}$ Dalam istilah sosiologi, pengukuran prestise diperoleh dari posisi opukasi individu-individu dalam masyarakat.7 Ragam semacam ini mempertimbangkan dimensi hierarki dan strata sosial masing-masing penutur. Ragam $H$ biasanya digunakan oleh kalangan ekonomi kelas menengah ke atas, mulai dari pejabat, sosialita, dan pengusaha. Sedangkan ragam $L$ digunakan dari kalangan ekonomi kelas menengah ke bawah yang meliputi masyarakat desa, pedagang kecil, dan lain sebagainya.

Ketiga, segi “warisan tradisi tulis-menulis”. Mengacu kepada banyaknya kepustakaan yang ditulis dalam $H$ dan dikagumi masyarakat tutur setempat. Tradisi tulis-menulis masa kini dianggap merupakan kelanjutan dari tradisi besar masa lampau.s Seperti yang diketahui, bahwa para ulama dan ilmuwan terdahulu melangsungkan tradis tulis-menulis dalam mengekspresikan gagasan pikiran sesuai dengan bidang keilmuan masing-masing. Tradisi ini berlangsung secara turun-temurun hingga

\footnotetext{
4 5

Kunjana Rahardi, Dimensi-dimensi Kebahasaan, (Jakarta: Penerbit Erlangga, 2006), hlm. 24.

Sumarsono, Sosiolinguistik, hlm. 191. bid.

Indra Ratna Irawati, Stratifikasi dan Mobilitas Sosial, (Jakarta: Pustaka Obor Indonesia, 2016), hlm. 55.

Sumarsono, Sosiolinguistik, hlm. 192.
} 
saat ini. Kepedulian dengan tradisi tulis-menulis akan memberi dampak positif bagi pembaca dan penerus keilmuan berikutnya. Sudah banyak dipastikan bahwa dalam tradisi ini menggunakan bahasa $H$. Ragam bahasa $H$ yang memiliki nilai kebakuan bahasa akan dijadikan pratinjau dan rujukan dalam penulisan aksara formal.

Keempat, segi “pemerolehan bahasa”. Dalam lingkup ini, terdapat perbedaaan dalam pemerolehan bahasa $H$ dan $L$. Ragam $L$ akan dipakai untuk berbicara dengan anak-anak dan dipakai diantara anak-anak itu, sehingga $L$ itu dipelajari secara normal dan tanpa kesadaran. Ragam $H$ itu selalu menjadi bahasa tambahan, ragam yang dipelajari setelah $L$ dikuasai, biasanya melalui pengajaran formal di sekolah.9 Pernyataan ini bisa disebut dengan pemerolehan bahasa pertama (B1) dan bahasa kedua (B2). Dalam studi Psikolinguistik, adanya B1 terjadi secara alamiah dan natural dengan menyesuaikan kondisi lingkungan, sedangkan B2 harus dipelajari secara intens baik dengan cara tempuh pendidikan formal maupun non-formal. Seseorang yang telah mahir berbahasa $L$ (B1) dikarenakan ia selalu berinteraksi dengan teman sebaya dan maupun bawahannya secara intens. Akan tetapi, ia akan mengalami kelambaan dalam menguasai bahasa $H(\mathrm{~B} 2)$, karena pemerolehan bahasa $H$ akan diajarkan dalam situasi-situasi formal baik dalam pendidikan maupun yang lain setelah sesorang menguasai B1 dengan baik.

Kelima, segi "pembakuan bahasa”. Bahasa baku merupakan ragam gaya bahasa yang cara pengucapan dan penulisannya sesuai dengan kaidah-kaidah standar. Kaidah standar bisa berupa pedoman ejaan (EYD), tata bahasa baku, dan kamus umum.10 Bahasa standar ialah bahasa yang dianggap betul oleh masyarakat pemakainya. Bentuk dan model bahasa ini menjadi percontohan dalam seluruh masyarakat. Fungsi dari bahasa baku adalah sebagai lingua franca di dalam masyarakat yang menggunakan berbagai dialek.11 Maka dari itu, bahasa $H$ diutamakan

\footnotetext{
9

Ibid. Hipotesis pemerolehan dan belajar bahasa adalah hipotesis yang menyatakan bahwa anak kecil dalam proses menguasai bahasa pertama terjadi secara ambang sadar dan bersifat alamiah (natural). Proses ini disebut pemerolehan (Acquisition). Orang dewasa dalam proses menguasai bahasa kedua atau bahasa asing terjadi secara sadar (Consiousness) melalui bentuk-bentuk bahasa dan mewujudkannya dalam bentuk verbal. Orang dewasa menguasai bahasa melalui kaidah-kaidah formal bahasa. Proses ini disebut belajar (Learning). Kesimpulannya, bahwa proses penguasaan bahasa dewasa berbeda dengan anak kecil. Lihat dalam Pranowo, Teori Belajar Bahasa, (Yogyakarta: Pustaka Pelajar, 2016), hlm. 75.

Ernawati Waridah, EYD \& Seputar Kebahasaan Indonesia, (Jakarta: Kawan Pustaka, 2006), hlm. 186. 
dalam pembakuan bahasa. Kamus, tata bahasa, petunjuk lafal, dan buku-buku mengenai pemakaian bahasa yang benar ditulis dalam ragam $H$. Kaidah alfabet dan ejaan bagi $H$ disusun tidak terlalu banyak variasanya. Jarang sekali ada studi tentang L.12 Dalam studi filsafat bahasa, jika bahasa mempunyai pembakuan yang disebabkan adanya beberapa pendukung, maka bahasa akan memiliki kemartabatan dan kewibawaan yang tinggi. Akan tetapi, beberapa faktor dapat mempengaruhi pergeseran bahasa baku menjadi tidak baku, diantaranya adalah pemahaman generasi baru yang berbeda, pengaruh bahasa lain, perkembangan cara hidup, inovasi khas, dan perubahan gramatika. 13

Keenam, segi "tata bahasa". Tata bahasa bisa disebut dengan istilah gramatikal yang sudah lazim pada tata bahasa tradisional. J.D Parera berpendapat bahwa gramatikal biasanya dihubungkan dengan modalitas dan kasus. Oleh karena itu, gramatikal berusaha mengelompokkan partikel-partikel bahasa sesuai dengan tata bahasa.14 Dalam segi ini, tata bahasa merupakan salah satu fungsi diglosia yang memandang bahwa terdapat perbedaan tata bahasa $H$ dan $L$, meskipun dalam satu bahasa yang sama. Misalnya, terdapat pola struktur gramatikal dalam bahasa Arab fuṣhā (H) dan bahasa Arab 'ämiyah (L). Meskipun kedua tata bahasa ini sudah dibakukan dalam tata bahasa Arab fuṣhā, keberadaan tata bahasa Arab ämiyah lebih sering digunakan masyarakat Timur Tengah dengan berbagai ragam dialeknya. Fungsi ini paling dominan digunakan oleh masyarakat diglosis Timur Tengah, sehingga fungsi ini menduduki level yang paling tinggi.

Ketujuh, segi “kosa kata”. Dalam diglosia, sebagian kosa kata bahasa $H$ hampir sama dengan bahasa $L$. Bahkan sebagian kata dari $L$ meminjam $H$, ataupun sebaliknya. Salah satu contoh masyarakat menyebut istilah "dahar" (Jawa) yang berarti "makan" dan mengisyaratkan kepada orang yang lebih tua, maka istilah "maem" diisyaratkan kepada anak yang memiliki usia lebih rendah daripada penutur. Segi kosa kata dalam tata diglosia merupakan segi yang sering digunakan oleh masyarakat diglosis. Segi ini merupakan diksi yang harus dipilih oleh penutur ketika ia akan

\footnotetext{
Sumarsono, Sosiolinguistik, hlm. 193.

Soepomo, Filsafat Bahasa, hlm. 50-58.

14 J.D.Parera, Morfologi Bahasa, (Jakarta: Gramedia Pustaka Utama, 2007), hlm. 96.
}

13 
berbicara dengan mitra tutur. Dalam memilih kosa kata yang tepat, seorang penutur harus mempertimbangkan beberapa hierarki, seperti hierarki sosial, usia, mitra, dan lain sebagainya.

Kedelapan, segi "fonologi". Menurut Ferguson, sistem bahasa $H$ dan $L$ itu membentuk struktur fonologi tunggal. Fonologi $L$ merupakan sistem dasar dan unsur-unsur sebaran fonologi $H$ merupakan sub sistem (sistem bawahan) atau parasistem (sistem atasan). Tetapi tidak bisa dikatakan, di sana ada struktur yang berbeda.15 Dalam dimensi linguistik, aspek fonologi merupakan aspek pertama yang harus dikenal oleh masyarakat bahasa, karena dimensi ini akan menjadi pengembang dalam dimensi-dimensi bahasa selanjutnya seperti morfologi, sintaksis dan semantik. Ragam fonologi yang dimiliki $H$ seutuhnya akan dimiliki $L$. Namun, segi ini tidak terlalu diperdebatkan oleh beberapa linguis pada terma diglosia.

\section{Antara Bilingualisme dan Diglosia.}

Hampir ada kemiripan dalam memdefinisikan kedua terma tersebut. Leonard Bloomfield mengartikan bilingualisme (kedwibahasaan) sebagai penguasaan seseorang yang sama baiknya atas dua bahasa. Kemudian Uriel Weinreich mengartikan kedwibahasaaan diartikan sebagai pemakaian dua bahasa oleh seseorang secara bergantian. Sedangkan menurut Einar Haugen mengartikannya sebagai kemampuan seseorang yang menghasilkan tuturan yang lengkap dan bermakna dalam bahasa lain.16 Istilah kedwibahasaan sering dipakai untuk menunjuk pada pengertian penggunaan dua bahasa oleh seseorang atau suatu masyarakat.17 Untuk dapat menggunakan dua bahasa tentunya seseorang harus menguasai dua bahasa itu. Pertama, bahasa itu sendiri atau bahasa pertamanya (B1) dan bahasa kedua (B2). Orang yang menggunakan bahasa kedua (B2) tersebut disebut orang yang bilingual (kedwibahasaan). Sedangkan kemampuan untuk menggunakan dua bahasa disebut bilingualitas. Selain istilah bilingualisme, juga digunakan istilah multibilingualisme

\footnotetext{
15 Sumarsono, Sosiolinguistik, hlm. 194.

16

Kushartanti, dkk, Pesona Bahasa: Langkah Awal Memahami Linguistik, (Jakarta: Gramedia Pustaka Utama, 2005), hlm. 58.

17 Sarwiji Suwandi, Serbalinguistik: Mengupas Pelbagai Praktik Berbahasa, (Surakarta: UNS Press, 2008), hlm. 11 .
} 
yakni keadaan yang digunakan lebih dari dua bahasa oleh seseorang dalam pergaulannya dengan orang lain secara bergantian.

Sedangkan, terma diglosia merupakan suatu situasi bahasa dimana terdapat pembagian fungsional atas variasi-variasi bahasa atau bahasa-bahasa yang ada di masyarakat. Diglosia merupakan situasi pemakaian bahasa yang stabil karena setiap bahasa diberi keleluasaan dalam menjalankan fungsi kemasyarakatannya secara proposional.18 Terdapat perbedaan fundamental dalam mengartikan antara terminologi diglosia dan bilingualisme. Terma diglosia lebih mengarah pada penggunaan satu bahasa tertentu yang ditinjau dari sisi fungsionalitas bahasa dan hierarki kelas masyarakat tutur. Diglosia lebih memainkan peran variasi bahasa, dialek dan ragam tutur dalam tataran komunikasi verbal dalam komunitas tertentu. Istilah bahasa yang dikenal dalam diglosia adalah ragam $H$ (High Class) dan ragam $L$ (Low Class). Ragam $H$ digunakan berdasarkan analisis hierarki kelas sosial level menengah ke atas dan keadaan formal dan ragam $L$ digunakan dalam hierarki kelas sosial kebawah dan keadaan informal dan non formal. Sedangkan, bilingualisme merupakan penggunaan dua bahasa dalam komunitas tertentu yang akan melahirkan proses campur kode dan alih kode dalam tataran komunikasi verbal.19 Istilah yang memainkan peran dalam bilingualisme adalah B1 dan B2. B1 yang merupakan bahasa bawaan komunikator dalam sisi genealinguistik yang akan membawa dampak pada proses keberhasilan B2.

Kendati demikian, ekstalansi bilingualisme sangat tergantung dengan folklore masing-masing masyarakat pengguna bahasa. Folklore dalam tatanan masyarakat tutur yang dibentuk dengan hierariki bahasa sejatinya menjadikan masyarakat lebih terampil dalam mengeksplorasi gagasan-gagasan ide yang ada dalam pikiran yang mampu diekspresikan melalui bahasa. Bilingualisme akan menjadi sebuah keadaan yang menarik dalam membentuk dinamika kebudayaan masyarakat tutur setempat. Sering dijumpai di beberapa tempat yang menggunakan bilingualisme akan tetapi folklore B1 masih dominan dalam mempengaruhi B2,

\footnotetext{
18 I Dewa Putu Wijana \& M. Rohmadi, Sosiolinguistik, hlm. 34.

19

Campur kode dapat didefinisikan sebagai penggunaan yang lebih dari satu bahasa atau kode dalam satu wacana menurut pola -pola yang belum jelas. Sedangkan alih kode adalah pergantian pemakaian bahasa atau dialek. Alih kode hanya dilakukan oleh dua pihak yang memiliki dua komunitas bahasa yang sama. Lihat, dalam Abdul Chaer dan Leonie Agustina, Sosiolinguistik, (Jakarta: Rieneke Cipta, 2004), hlm. 72.
} 
sehingga menghasilkan gejala-gejala interferensi bahasa yang keluar dari tatanan baku. Tidak masalah jika penggunaan interferensi bahasa ternyata mampu menimbulkan minat yang tinggi dalam membentuk sebuah lingkungan bilingualisme. Keberanian dalam mengujarkan B2 yang tentunya tidak semudah mempelajari B1. Bagi kalangan yang baru masuk komunitas bilingualisme, sikap ini patut untuk diberi apresiasi. Sejatinya, tidak mudah melepas folklore B1 secara langsung. Upaya pelepasan folklore B1 sangat berpengaruh pada proses pembentukan B2 yang akan hilang sejalan dengan waktu yang dibutuhkan.

\section{Bahasa Arab dalam Tradisi Pesantren.}

Dunia pesantren menjadi bagian yang tidak terpisahkan dari sejarah panjang umat Islam Indonesia. Pada masa-masa sulit, yaitu jauh sebelum kemerdekaan dan masa revolusi mempertahankan kemerdekaan yang baru dicapai negaranegara Indonesia, banyak pesantren telah berdiri di Indonesia.20 Dalam pandangan Azra, dunia pesantren adalah dunia tradisional Islam, yakni dunia yang mewarisi dan memelihara kontinuitas tradisi Islam yang dikembangkan ulama dari masa ke masa, tidak terbatas pada periode tertentu dalam sejarah Islam. Dalam perjalanan sejarahnya, pesantren terus melakukan akomodasi dan konsensi tertentu untuk menemukan pola yang dipandangnya cukup tepat guna menghadapi perubahan-perubahan yang kian cepat dan luas.21 Kemudian dalam perkembangannya, akomodasi dalam dunia pesantren yang kiat melejit hingga saat-saat ini tidak menghilangkan nilai-nilai dasar Islam yang ditekankan pada aspek syariah dan tasawuf. Kedua keilmuan ini menjadi pilar utama yang kokoh dalam eksistensi pesantren hingga saat ini. Kedua keilmuan tersebut merupakan prinsip-prinsip dasar Islam yang berbahasa Arab.

Bahasa Arab merupakan bahasa pengantar yang diajarkan di berbagai pesantren Salaf (Tradisional) dan Khalāf (Modern). Bahasa Arab mempunyai kedudukan yang tinggi dalam dunia pesantren. Bagaimana

\footnotetext{
20 Azyumardi Azra, Pendidikan Islam: Tradisi Dan dan Modernisasi di Tengah Tantangan Milenium III, (Jakarta: Kencana Perdana Media Group, 2012), hlm. 132. 
tidak? Segala ilmu-ilmu agama yang bersumber dari al-Qur'an, Hadits, dan kitab-kitab semua berbahasa Arab. Melihat kenyataan ini, bahasa Arab menjadi bahasa yang wajib diajarkan di pesantren guna menjadi alat untuk memahami ilmu- ilmu agama tersebut. Semenjak dahulu, bahasa Arab telah diajarkan di pesantren baik Salaf maupun Khalāf, yang mempunyai perbedaan metodologis dalam pembelajarannya.22 Metodologi pembelajaran bahasa Arab yang diajarkan di pesantren Salaf secara garis besar menggunakan pendekatan tradisional dan lebih bersifat konservatif sehingga metodologi pembelajaran yang digunakan lebih mengarah kepada keterampilan membaca (mahārah qira'ah). Karena dalam pesantren Salaf lebih menekankan pembelajaran kitabkitab kuning yang membutuhkan analisis bahasa, bukan berbahasa. Sedangkan, metodologi pembelajaran bahasa Arab di pesantren Khaläf menggunakan pendekatan komunikatif, sehingga metode dan teknik pembelajaran yang digunakan lebih mengarah kepada keterampilan berbicara (mahārah kaläm). Pesantren ini lebih menekankan aspek berbahasa daripada analisis bahasa.

Pesantren Salaf merupakan pesantren yang mendedikasikan dirinya sebagai pesantren kitab kuning. Kegiatan sehari-hari yang ada di pesantren ini tidak bisa lepas dari kitab kuning sebagai materi yang harus diajarkan dalam mendalami ilmu-ilmu agama seperti fikih, tasawuf, kalam, tata bahasa Arab, dan sebagainya. Sehingga pendekatan pembelajaran bahasa Arab (PBA) yang digunakan dalam mempelajari kitab-kitab kuning adalah pendekatan tradisional dan struktral. Pendekatan tradisional atau yang disebut Teacher-Centered Approach adalah suatu pendekatan belajar yang berdasar pada pandangan bahwa mengajar adalam menanamkan pengetahuan dan keterampilan. Proses pembelajaran tergantung pada guru. Guru bertugas mengajar dan memberi pengetahuan kepada para siswa, sedangkan siswa hanya mendengarkan saja.23 Kemudian,

\footnotetext{
22

Pada dasarnya, ada dua pendekatan dalam pembelajaran pengajaran bahasa Arab, yaitu Integrated System dan yang kedua Sparated System. Integrated atau All In One System dimaksudkan agar dalam pembelajaran bahasa, kita harus melihat bahasa itu dengan kesatuan yang utuh, bukan sebagai bagian-bagian yang terpisah dan masingmasing berdiri sendiri. Adapun Sparated System justru sebaliknya, dalam arti bahasa itu terdiri dari beberapa aspek gramatik, morfologis, sintakisis, semantis, leksikal dan stilistik yang harus diajarkan secara terpisah sesuai dengan cabangnya masing-masing. Fathul Mujib, Rekonstruksi Pendidikan Bahasa Arab dari Pendekatan Konvensional ke Integratif Humanis, (Yogyakarta: Pedajogja, 2010), hlm. 83.
}

23

Rusman, dkk, Pembelajaran Berbasis Teknologi Informasi dan Komunikasi Mengembangkan Profesionalitas Guru, (Jakarta: PT. Raja Gravimdo Persada, 2012), hlm. 44. 
pendekatan tradisional adalah salah satu pendekatan dalam pembelajaran bahasa yang dilandasi oleh asumsi yang menganggap bahasa sebagai kaidah. Atas dasar tersebut, timbul pemikiran bahwa pembelajaran bahasa harus mengutamakan penguasaan kaidah-kaidah bahasa atau tata bahasa. Sedangkan metode PBA yang digunakan adalah metode Gramatika- Terjemah atau yang disebut Qawāid wa Tarjamah, yang merupakan gabungan dari metode gramatika dan metode terjemah.24 Adapun model-model PBA yang digunakan meliputi empat model, yakni Sorogan, Bandongan/ Wektonan, Muhāafazah dan Syawir/Baḥs al-Masāil. Pertama, model Sorogan. Sorogan merupakan kegiatan pembelajaran bagi para santri yang lebih menitikberatkan pada pengembangan kemampuan individu di bawah bimbingan seorang kyai atau ustadz.25 Prosedur kegiatan pembelajaran ini adalah santri membaca kitab kuning dan disimak langsung oleh ustadz. Setelah santri selesei membaca beberapa kalimat yang ada dalam kitab, santri menerjemahkan dan menganalisis tata bahasa Arab dalam kalimat-kalimat tersebut secara deduktif. Analisis tata bahasa meliputi kaidah sintaksis (Naḥwu) dan morfologi (Șarf). Kedua, model Bandongan/Wetonan. Bandongan/Wetonan dilakukan oleh seorang kyai atau ustadz terhadap sekelompok santri untuk menyimak apa yang dibacanya dari sebuah kitab, seorang kyai atau ustadz dalam ini membaca, menerjemahkan, menerangkan dan seringkali mengulas teks-teks kitab berbahasa Arab (gundul). Sementara itu, santri dengan memegang kitab yang sama masing -masing memberikan harakāt, mencatat simbol-simbol kedudukan kata, arti kata -kata langsung di bawah kalimat dan keteranganketerangan lain yang dianggap penting dan dapat memahami teks.26 Ketiga, model Muḥāfazah. Muḥāfazah merupakan hafalan-hafalan tata bahasa Arab yang mengacu pada nazam dan bait materi pembelajaran masing-masing seperti Nahwwu dan Șarf.

\footnotetext{
24

Dalam metode ini, pembelajaran bahasa asing lebih ditekankan pada kaidah-kaidah bahasa agar mencapai keterampilan membaca, menulis dan menerjemah. Metode ini dapat dikatakan ideal daripada salah satu atau dari keduanya dari metode ini (Gramatika dan Terjemah), terlebih dahulu diajarkan dan kemudian pelajaran menerjemah dan pelaksanaan sejalan pun. Metode Gramatika adalah metode yang menekankan pada penghafalan aturan gramatika dan sejumlah kata tertentu yang kemudian dirangkai menurut tata bahasa yang berlaku. Sedangkan metode Terjemah adalah sebuah metode yang di dalamnya menerjemahkan dari bahasa sumber ke dalam bahasa sasaran bersamaan dengan penerapan aturan-aturan tata bahasa. Ahmad Izzan, Metodologi Pembelajaran Bahasa Arab, (Bandung: Humaniora, 2004), hlm. 100.

25

Abdullah Hamid, Pendidikan Karakter Berbasis Pesantren: Pelajar dan Santri dalam Era IT \& Cyber Culture, (Surabaya: Imtiyaz, 2017), hlm. 54.

26

Ibid., hlm. 55
} 
Tata bahasa Arab dihafal sedemikian rupa dengan sedetail-detailnya baik secara mandiri atau kelompok. Urgensi model ini adalah, setelah santri mampu menghafal tata bahasa Arab berdasarkan urutan nazam dan bait, santri dapat menganalisis strukur-struktur gramatika bahasa Arab dalam kitab kuning. Keempat, model Syāwir/Baḥs al-Masāil. Syāwir/Baḥis al-Masāil merupakan forum ilmiah yang membahas masalah diniyah seperti ibadah, akidah dan masalah agama pada umumnya.27 Dari kelima model PBA tersebut dapat disimpulkan bahwa PBA di pesantren Salaf lebih menekankan pada aspek bahasa yang berorientasi pada keterampilan membaca (Mahārah Qira'ah).

Di sisi lain, pesantren Khalāf yang merupakan pesantren modern memiliki cara tersendiri dalam manajemen PBA. Corak PBA yang diajarakan di pesantren ini lebih sejalan dengan pemikiran aliran linguistik strukturalisme yang memandang bahwa bahasa adalah yang diujarkan dan bukan sebuah tulisan. Lahirnya berbahasa adalah karena faktor kebiasaan yang didorong dari stimulus dan respons. Manajemen PBA yang ada dalam pesantren ini lebih berorientasi pada keterampilan berbicara (Mahārah Kalām). Berbahasa Arab merupakan kegiatan yang wajib dilaksanakan oleh semua santri baik di dalam kelas maupun di luar kelas. Paradigma PBA yang berorientasi pada keterampilan berbicara akan membawa pendekatan, metode dan teknik PBA yang berbeda dengan pesantren Salaf. Pendekatan PBA yang digunakan di pesantren Khalāf adalah pendekatan komunikatif. Pendekatan komunikatif adalah proses pembelajaran yang berbasis komunikasi, artinya pembelajaran yang dilandasi oleh teori komunikasi dan fungsi bahasa. Tujuan pembelajaran ini adalah mengembangkan kemampuan komunikasi secara prosedur pengajaran empat keterampilan berbahasa (mendengar, berbicara, membaca dan menulis) yang mengakui interdepensi atau saling ketergantungan antara bahasa dan komunikasi.28 Sedangkan, metode PBA yang digunakan adalah metode Mubāsyarah (langsung). Metode Mubāsyarah merupakan metode yang memprioritaskan pada

\footnotetext{
27 Ibid., hlm. 56.

28

Ahmad Abduh 'Awadh, al-Madākhil Ta'līm al-Lughah al-'Arabiyyah, (Makkah: Jāmi'ah Ummu al-Qurā, 2000), hlm. 65 .
} 
keterampilan berbicara.29 Cara menyajikan materi bahasa asing adalah guru langsung menggunakan bahasa asing (B2) tersebut sebagai bahasa pengantar dan tanpa menggunakan bahasa ibu (B1) sedikitpun. Sehingga, melalui metode ini, siswa dapat langsung melatih kemahiran berbicara tanpa menggunakan B1.30 Penggunaan pendekatan dan metode ini dinilai lebih efektif dalam pengelolaan PBA di pesantren yang lebih menekankan kemampuan keterampilan berbicara (Mahārah Kalām). Dari reduksi pendekatan dan metode tersebut, dapat dilahirkan beberapa model PBA kiranya digunakan dalam pesantren Khalāf. Model-model PBA yang ada di pesantren Khalāf diantaranya adalah Iḍ̂̄f, Muḥādasiah, dan Muhāḍarah. Pertama, Iḍāf adalah penyajian mufradāt yaumiyyah dari ustadz kepada santri. Asumsi penyajian mufradāt adalah agar santri hafal mufradāt dan mampu mengaplikasikannya dalam percakapan bahasa Arab. Tema-tema mufradāt adalah seputar percakapan sehari-hari yang disesuaikan dengan kebutuhan akademik. Kedua, Muḥädasiah merupakan latihan bercakap-cakap bahasa Arab yang diwajibkan oleh pondok pesantren kepada santri selama mereka tinggal di dalamnya.31 Kegiatan ini juga bisa disebut dengan Muḥāwarah. Setelah santri hafal tentang mufradāt sesuai tema yang diberikan, santri diberi kesempatan untuk mempraktikkan dengan bentuk percakapan dalam sesi ini. Ketiga, Muhạdarah, adalah pendidikan berpidato bahasa ibu dan bahasa asing yang diselenggarakan oleh pondok pesantren dalam beberapa kali dalam sepekan. Bahasa yang digunakan dalam kegiatan ini meliputi bahasa Inggris, Arab dan Indonesia. Akan tetapi, kebanyakan pesantren Khaläf cenderung menggunakan bahasa Inggris dan Arab. Mental santri dipupuk dan dilatih menjadi da'i secara berkala agar kelak mempunyai mental dan keberanian dalam berdakwah di masyarakat ketika pulang dari pesantren. Ketiga model PBA tersebut merupakan ciri khas yang dimiliki oleh pesantren Khalāf. Dengan akhir kata, berbagai metodologi PBA yang diajarakan di pesantren Salaf dan Khalāf ini adalah guna mereaktualisasikan kegiatan belajar bahasa Arab agar menjadi lebih baik dan menghasilkan generasi-generasi yang terampil dalam berbahasa Arab.

\footnotetext{
29 Radliyah Zainuddin, Metodologi \& Strategi Alternatif Pembelajaran Bahasa Arab, (Yogyakarta: Pustaka Rihlah Group, 2005), hlm. 39.

30 Tayar Yusuf, Metodologi Pengajaran Agama \& Budaya, (Jakarta: PT. Rajagravindo Persada, 1995), hlm. 153.

31 Abdullah Hamid, Pendidikan Karakter Berbasis Pesantren, hlm. 56.
} 


\section{Eksplanasi Sosiokultural Komunitas Diglosis dalam Upaya Pergeseran dan Pemertahanan Bahasa Daerah (Language Maintenance) di Indonesia.}

Setelah membahasa terminologi diglosia, bilingualisme dan diglosia, bahasa Arab dan tradisi pesantren, hingga akhirya mampu mereduksi kajian-kajian konseptual yang menghasilkan sintesis ilmiah yang priori, maka dialektika tersebut membawa dampak pada kajian yang sekiranya relevan dalam konstelasi sosiologi bahasa, yang pada akhirnya kajian ini akan berdialektika dengan disiplin keilmuan lain seperti psikologi dan lingustik Arab.

Pergeseran bahasa dan pemertahanan bahasa sebenarnya seperti dua sisi mata uang; bahasa menggeser bahasa lain atau bahasa yang tak tergeser oleh bahasa; bahasa yang tergeser adalah bahasa yang tidak mampu mempertahankan diri. Kedua kondisi ini merupakan akibat dari pilihan bahasa dalam jangka panjang (paling tidak tiga generasi) dan bersifat kolektif (dilakukan oleh semua masyarakat tutur) . Pergeseran bahasa berarti suatu komunitas meninggalkan suatu bahasa sepenuhnya untuk memakai bahasa lain. Bila pergeseran sudah terjadi, para komunitas itu secara kolektif memilih bahasa baru. Dalam pemertahan bahasa, komunitas secara kolektif menentukan untuk melanjutkan memakai bahasa yang sudah baiasa dipakai. Ketika komunitas memilih bahasa baru, di dalam ranah yang semula diperuntukkan bagi bahasa lama, itulah mungkin merupakan tanda bahwa pergeseran bahasa sedang berlangsung. 32 Gejala ini jika terus berlangsung maka akan menimbulkan kepunahan bahasa. Kepunahan bahasa terjadi manakala komunitas bergeser ke bahasa baru secara total sehingga bahasa terdahulu tidak terpakai lagi.33

Secara sosiologis, bahasa merupakan salah satu unsur kebudayaan yang dihasilkan dari komunitas masyarakat tutur setempat. Bahasa bersifat organis, jika bahasa itu digunakan secara konsisten oleh masyarakat tutur setempat dan masyarakat mampu memfilter interferensi bahasa-bahasa asing (B2), maka eksistensi B1 akan terus terjaga. Dan jika masyarakat tutur setempat tidak konsisten dalam memelihara kemartabatan B1,

\footnotetext{
32 Sumarsono, Sosiolinguistik, hlm. 231-232.

33

Ibid., hlm. 283.
} 
maka B1 tidak akan survive dalam menjadi simbol komunitas tertentu. Dampak dari manuver globalisasi yang salah satunya adalah adanya Masyarakat Ekonomi Asean (MEA) secara eksplisit akan memakasa masyarakat tutur di belahan kancah Asean untuk berdialektika dengan menggunakan bahasa asing. Ragam etnik bahasa daerah yang menjadi simbol dan jenis kelamin masyarakat dan komunitas tertentu sedikit akan mengalami pergeseran yang mengarah pada campur kode dan alih kode bahasa, sehingga potensi bilingualisme akan semakin berkembang. Gejala ini akan membawa pada minimnya masyarakat tutur setempat dalam mempertahankan bahasa daerah.

Tidak hanya dalam komunitas masyarakat Asean, salah satu fenomena yang menjadi keprihatinan dunia saat ini salah satunya adalah punahnya bahasabahasa daerah di sejumlah belahan dunia tak terkecuali di Indonesia. Menurut penelitian, bahasa daerah yang jumlah penuturnya di bawah 100.000 orang sudah tergolong sebagai bahasa yang akan punah. Di Ambon provinsi Maluku menurut laporan pusat bahasa, ada bahasa daerah yang penuturnya tinggal satu orang. Bisa dikatakan bahasa itu akan segera sirna dari bumi Nusantara. 34 Jumlah bahasa di Indonesia sampai sekarang belum ada jawaban yang pasti. Berdasarkan perkiraan umum yang disampaikan orang awam, di seluruh Indonesia terdapat 200 hingga 300 bahasa daerah. Namun berdasarkan penelitian kelompok SIL tahun 2001, di Indonesia terdapat 726 bahasa daerah (dengan catatan tidak termasuk tiga bahasa yang telah punah). Diantara semua bahasa-bahasa di Indonesia, ada bahasa yang jumlah penuturnya jutaan dan adapula bahasa yang berapa ribu, beberapa ratus, bahkan hanya beberapa puluh saja penuturnya. Ada 13 bahasa terbesar di Indonesia, yaitu yang jumlah penuturnya lebih dari satu juta, demikian masih ada 713 bahasa yang dituturkan kurang dari satu juta orang. 35 Secara sosiokultural, jumlah bahasa demikian merupakan bentuk kekayaan bahasa daerah yang dimiliki Indonesia dan belum tentu dimiliki oleh bangsa lain. Jika dicermati lebih dalam, bahasa daerah yang memiliki jumlah penutur lebih dari satu juta orang, maka bisa diasumsikan bahwa masyarakat tutur setempat mampu menjaga konsistensi bahasa mereka

\footnotetext{
34 Apolonius Lase, Kamus LI NIHA Nias-Indonesia, (Jakarta: Buku Kompas, 2011), hlm. 13. 35 Kushartanti, dkk, Pesona Bahasa, hlm. 185.
} 
sebagai simbol komunitas. Akan tetapi, tidak semuanya bahasa daerah di Indonesia memiliki gejolak yang sama. Semakin banyak masyarakat menggunakan bahasa daerah, maka semakin survive nilai kebahasaan itu.

Ada berbagai sebab atau alasan mengapa suatu bahasa punah atau tidak digunakan lagi oleh penutur-penuturnya. Satu diantaranya adalah adanya dominasi bahasa atau dialek yang lebih besar baik secara demografis, ekonomis, sosial, atau politis. Pemeliharaan bahasa tidak cukup hanya dengan usaha mendeskripsikan sistem kebahasaan dan wilayah pemakaiannya, seperti yang telah dilakukan oleh para linguis selama ini. Namun, tidak kalah penting itu semua adalah penumbuhan rasa bangga dalam diri penutur-penuturnya. 36 Upaya pemertahanan bahasa daerah tidak akan berjalan dengan baik jika tidak melibatkan peran dan kontribusi masyarakat tutur setempat. Selain penumbuhan rasa bangga pada bahasa daaerah, peran dan konstribusi masyarakat tutur bisa menjadi barometer pemertahanan bahasa daerah. Begitu juga peran pemerintah daerah setempat yang sekiranya perlu dilibatkan dalam menangani kasus ini. Seperti halnya pemerintahan Mesir di wilayah Timur Tengah mempunyai majelis dan organisasi pusat bahasa yang spesifik melestarikan bahasa Arab fusḥa di tengah ramainya variasi dan dialek Arab 'àmiyyah pada masyarakat Mesir. Begitu juga peran Gereja Katolik di Vatikan Roma Italia. Selain digunakan sebagai tempat peribadatan bagi kaum Katolik, gereja ini digunakan untuk melestarikan bahasa Itali yang baku. Dengan demikian, pemerintah juga bisa membuat kebijakan memasukkan materi pelajaran bahasa daerah di setiap jenjang pendidikan dasar dan menengah. Muatan ini bisa dibentuk sebagai kurikulum yang wajib yang harus diajarkan di sekolah-sekolah wilayah. Upaya-upaya demikian yang perlu diperhatikan oleh pemerintah setempat dalam mempertahankan bahasa daerah. Jika bahasa daerah mampu bertahan dalam suatu daerah, maka salah satu nilai kebudayaan yang ada di daerah tersebut masih cukup dibilang survive.

36 I Dewa Putu Wijana \& M. Rohmadi, Sosiolinguistik, hlm. 89. 


\section{Diglosia Bahasa Arab Pesantren dan Upaya Pemertahanan Bahasa Daerah.}

Dalam pandangan Ferguson seorang linguis berkebangsaan Perancis, diglosia merupkan suatu situasi yang di dalamnya ada dua ragam dari satu bahasa hidup berdampingan dengan peran masing-masing dalam masyarakat itu.37 Terminologi ini yang akan membawa arah wacana bahwa permasalahan diglosia bisa terjadi dimanapun masyarakat tutur itu tinggal. Bahasa yang merupakan produk dari salah satu kebudayaan masyarakat pastilah mengikat dan hidup berdampingan dengan masyarakat. Begitu juga masyarakat pesantren yang memiliki SDM seperti kyai, ustadz, pengurus pesantren dan santri. Keempat unsur tersebut merupakan subjek sekaligus objek komunikasi. Dalam catatan sejarah, tidak ada pesantren di Indonesia yang tidak mengajarkan bahasa asing. Semua pesantren mengajarkan bahasa asing meskipun hanya salah satu bahasa semisal bahasa Arab atau Inggris. Hal ini mengindikasikan bahwa pesantren mempunyai signifikasi yang tinggi dalam pertumbuhan dan perkembangan bahasa asing di Indonesia.

Penggunaan bahasa Arab di pesantren akan membawa bentuk diglosia sebagaimana fungsinya. Diglosia bahasa Arab pesantren akan tumbuh dengan kurun waktu tertentu dengan menyesuaikan fungsi penggunaan. Sebagaimana di pesantren Salaf, diglosia bahasa Arab menyesuaikan PBA yang ada di pesantren tersebut. Ketika santri mengaji dengan kyai dan ustadznya dengan model Sorogan,Bandongan/Wetonan, Muḥāfazah, dan Syāwir/Baḥis al-Masāil, maka mereka menggunakan bahasa Arab 'fuṣhā dengan level $H$ dalam berbagai aspek dan fungsi diglosia yang meliputi fonologi, tata bahasa, prestise, tradisi tulis menulis dan pembakuan bahasa. Dalam PBA demikian, fungsi $H$ sangatlah berperan penting sebagai pembentukan dan pelestarian bahasa Arab fuṣhā. Bahasa fuṣhā menempati level $H$ karena mampu mentransmisikan antara wacana Arab baku dan komunikasi Arab, sehingga bentuk variasi wacana Arab dalam PBA dengan model-model tersebut akan menempati ruang yang memiliki prestise tinggi. Faktor penggunaan $H$ juga dikarenakan dalam kajian kitab-kitab klasik yang menggunakan $H$, sehingga tradisi tulis-menulis yang berkaitan dengan model-model PBA tersebut relatif menggunakan

37 Sumarsono, Sosiolinguistik, (Yogyakarta: Pustaka Pelajar, 2017), hlm. 191 
$H$. Ketika santri berinteraksi dan berkomunikasi dengan para senior yang ada di pesantren tersebut, maka ia akan menggunakan ragam $H$ dan kadang menggunakan B1 formal. Akan tetapi, ketika santri berkomunikasi dengan teman sejawat dan dalam situasi informal dan non-formal, maka ia kebanyakan menggunakan ragam $L$ dan B1 informal-non formal. Di sisi lain, terdapat beberapa pesantren Salaf yang menggunakan bahasa Arab dalam komunikasi sehari-hari. Kebanyakan komunitas di pesantren Salaf berkomunikasi dengan B1.

Sedikit berbeda dengan kondisi PBA di pesantren Khalāf. Keberadaan diglosia bahasa Arab di pesantren ini memiliki nilai penggunaan $H$ dan $L$ secara sejajar. Model- model PBA seperti I⿳亠口冋f, Muḥādasiah, dan Muhādarah memiliki peran fungsi diglosia pada aspek fonologi, tata bahasa, prestise, kosa kata, pembakuan dan tradisi tulis menulis. Dalam PBA model Iḍ̂af, komunikasi bahasa Arab lebih mengarah pada level $H$. Mufradat yang disampaikan merupakan ragam bahasa Arab fuṣhā yang harus diajarkan dengan level $H$. Hal ini agar santri mempunyai pemahaman dasar bahasa Arab fuṣhā dengan baik. Kemudian dalam PBA yang menggunakan model Muḥādasंah, terkadang santri menggunakan level $H$ dan $L$. Level $H$ digunakan ketika ia berkomunikasi kepada kyai dan ustadznya, dan ketika berkomunikasi dengan teman sejawat dalam keadaan informal, non-formal, maka menggunakan $L$. Sedangkan pada PBA dengan model Muhāḍarah, santri cenderung menggunakan $H$. Kegiatan Muhạdarah merupakan kegiatan yang melatih keberanian santri dalam berdakwah. Sehingga komunikasi dengan level $H$ sangat ditekankan pada aspek ini karena akan masuk dalam keadaan formal. Untuk lebih jelas bisa melihat tabel diglosia bahasa Arab pesantren di bawah ini : 
Dari tabel tersebut dapat dimengerti bahwa keberadaan diglosia bahasa Arab antara pesantren Khalā $f$ dan Salaf mengalami sedikit perbedaan. Perbedaan ini ada muncul karena perbedaan tujuan dalam PBA yang dikonsep oleh masingmasing lembaga. Sebagaimana dibahas sebelumnya, bahwa PBA di pesantren Khalāf lebih bertendensi dan berorientasi pada mahārah kalām (keterampilan berbicara) sedangkan di pesantren Salaf lebih bertendensi dan berorientasi pada mahārah qira'ah (keterampilan membaca). Perbedaan tujuan PBA ini yang akhirnya membawa pada perbedaan pendekatan, metode dan model PBA di masing-masing lembaga. Lantas, apakah dengan adanya diglosia bahasa Arab tersebut berdampak pada pemertahanan bahasa daerah yang dibawa oleh masing-masing masyarakat tutur di pesantren tersebut? Pertanyaan ini yang akan menjadi benang merah dalam mendialogkan eksistensi diglosia bahasa Arab pesantren dan upaya pemertahanan bahasa daerah (B1) masyarakat tutur pesantren.

Sebagaimana diketahui, peran bahasa Arab di pesantren sangatlah penting bahkan dikatakan bahasa yang wajib dikomunikasikan secara verbal dan non verbal seperti halnya yang telah ditransmisikan ke dalam beberapa diglosia bahasa Arab pesantren di atas. Masyarakat tutur di pesantren secara eksplisit akan bersinggungan dan berinteraksi dengan bahasa Arab. Di sisi lain, komunitas masyarakat tutur yang ada di pesantren berasal dari berbagai daerah di Indonesia yang membawa bahasa daerah masing-masing. Bahasa daerah yang meraka bawa merupakan B1 yang sudah mengikat dalam sensori motorik kepribadian komunikan yang 
didapat dari proses pemerolehan bahasa. Ketika berdomisili di pesantren, mereka akan mengalami masa transisi komunikasi dari B1 (bahasa daerah) ke B2 (bahasa Arab). Secara perlahan, komunikasi dengan B1 akan ditinggalkan dan beralih ke B2 yang hingga akhirnya menimbulkan permasalahan bilingualisme, campur kode, dan alih kode. Apalagi kebijakan di pesantren Khalāf salah satunya adalah mewajibkan seluruh elemen yang domisili di pesantren untuk berbahasa Arab atau Inggris. Secara terus menerus, gejala ini akan membawa dampak hilangnya B1 dalam siklus yang cepat atau lambat. Faktor habit yang ditumbuhkan oleh masyarakat tutur di pesantren akan melahirkan komunitas berbahasa B2. Pengejawantahan B2 ini bisa dalam bentuk praktik pembelajaran bahasa dan komunikasi verbal. Ketika mereka getol berinteraksi dengan B2 secara konsisten, dan membentuk komunitas B2 dengan baik, secara perlahan eksistensi B1 akan meredup bahkan hilang dari jati dirinya dan dan berdampak pada aspek psikologis dan sosiologis. Ketika komunikan tidak lagi menggunakan B1 dalam berinteraksi dengan masyarakat saat pulang dari pesantren, maka komunikan akan merasa tertekan dan merasa bersalah, sehingga ia tidak mau lagi berinteraksi dengan masyarakat setempat dengan B1 dan menimbulkan pengucilan di mata masyarakat. Kenyataan ini akan menimbulkan sebuah afeksi masyarakat setempat dalam merespon keberadaan pesantren. Pesantren yang sebelumnya dinilai positif oleh beberapa kalangan akan mendapat stigma negatif jika permasalahan ini akan terus berlanjut. Lantas, bagaimana upaya pesantren dalam memanajerial sebuah lembaga demi menjaga dan melestarikan bahasa daerah masyarakat tutur masing-masing? Pertanyaan ini yang harus segera diseleseikan dalam perdebatan ini.

Pesantren sebagai media dakwah Islam harus mempertimbangkan beberapa aspek penting dalam setiap penentuan kebijakan. Salah satu kebijakan yang harus ada dalam pesantren adalah kebijakan mengelola bahasa. Pengelolaan bahasa ini yang nantinya akan membawa keberhasilan masyarakat tutur untuk terampil berbahasa asing maupun bahasa daerah. Resolusi yang harus ditempuh oleh pesantren dalam mengelola bahasa adalah; pertama, membentuk pusat bahasa. Dengan dibentuknya pusat bahasa dalam lembaga pesantren agar senantiasa mampu menyusun, mengontrol, mengadvokasi dan mengevaluasi kegiatan yang bernuansa bahasa di pesantren. Dan jika memang tidak 
ada lembaga pusat bahasa, manajerial bisa diserahkan ke pengurus harian bagian bahasa. Pusat bahasa atau pengurus bagian bahasa di pesantren seyogyanya mampu mengorganisir kegiatan kebahasaan yang telah berlangsung di pesantren serta mengevaluasi sebagai bahan pertimbangan ke depan dalam mengembangkan keterampilan berbahasa asing dan bahasa daerah masyarakat tutur pesantren. Kedua, melakukan reschedule dalam penggunaan bahasa. Dalam prosesnya, pengurus bisa menjadwalkan beberapa hari dalam tiap pekan kepada seluruh yang berdomisili di pesantren untuk menggunakan bahasa tertentu, semisal bahasa Arab atau bahasa Inggris, dan di hari yang tersisa untuk menggunakan bahasa daerah yang tentunya harus sesuai dengan frekuensi hari-hari yang telah ditentukan. Ketiga, mencanangkan beberapa kegiatan ekstrakurikuler yang bernuansa kebahasaan seperti adanya festival bahasa asing dan daerah. Keempat, memberikan apresiasi kepada mereka yang terampil dalam berbahasa asing dan daerah agar masyarakat tutur bisa merespon positif dalam kegiatan bahasa di pesantren. Kelima, memupuk jiwa masyarakat tutur pesantren untuk bangga dengan bahasa daerah masingmasing. Keberhasilan pemertahanan bahasa daerah tidak hanya dengan solusi sistem kebahasaan saja, tetapi perasaan bangga dalam melestarikan dan menggunakan bahasa daerah akan memiliki nilai yang cukup mendorong masyarakat tutur pesantren dalam menggunakan bahasa daerah. Beberapa resolusi ini setidaknya agar bisa membuat masyarakat tutur pesantren mampu dan terampil berbahasa asing dan bahasa daerah dengan pokok dan fungsi yang sama. Dengan istilah lain, bahasa daerah tidak seharusnya ditinggalkan oleh penuturnya mesikipun penutur memasuki komunitas yang menggunakan bahasa baru, karena kemartabatan bahasa daerah akan terangkat dan eksis jika masih digunakan. 


\section{PENUTUP \\ Kesimpulan}

Eksistensi pesantren tidak lepas dari peran bahasa Arab sebagai bahasa pengantar dalam mereaktualisasikan studi Islam. Peranan bahasa Arab di pesantren dengan aktualisasi PBA tentunya memiliki ragam pendekatan, metode dan model yang cukup variatif yang melahirkan diglosia. Konstelasi diglosia bahasa Arab pesantren dengan level $H$ dan $L$ akan membawa dampak pada pemertahanan bahasa daerah masyarakat tutur pesantren. Faktor folklore dan habit yang sangat mendukung B2 agar terus eksis, secara perlahan akan membawa arus kepada kurangnya masyarakat tutur pesantren dalam menggunakan bahasa daerah (B1) untuk komunikasi sehari-hari. Jika dilakukan secara konsisten, gejala ini akan membawa pada kepunahan B1.

Meskipun demikian, harus ada solusi yang nyata dari pesantren dalam menentukan kebijakan-kebijakan yang mengarah pada pemertahanan B2, seperti dengan mengadakan lembaga pusat bahasa, reschedule bahasa, mengadakan kegiatan-kegiatan kebahasaan, pemberian apresiasi serta memupuk masyarakat tutur pesantren untuk bangga dengan bahasa daerah masing-masing. Upaya ini akan membawa dampak positif terhadap pemertahanan bahasa daerah tanpa mengurangi kualitas dan kuantitas pembelajaran B2 di pesantren. Dengan akhir kata, masyarakat tutur diharapkan mampu berkomunikasi B2 dengan baik tanpa membuang B1.

\section{Saran}

Pesantren sebagai media dakwah Islam yang menjadi lembaga kepercayaan masyarakat harus mampu merekonstruksi kebijakan-kebijakan dalam berbagai aspek yang salah satunya adalah kebijakan mengelola bahasa. Bahasa sebagai media komunikasi masyarakat tutur di pesantren mempunyai urgensi tersendiri dalam pengejawantahannya. Pesantren tidak harus bersikap apatis dalam mengelola kebahasaan yang mengharuskan masyarakat tutur pesantren berkomunikasi dengan bahasa asing, akan tetapi pesantren harus mempunyai sikap afektif yang membutuhkan respon positif dan terbuka kepada masyarakat tutur dalam mengembangkan keterampilan berbahasa B1 dan B2. 


\section{DAFTAR PUSTAKA}

Awadh, Ahmad Abduh. (2000) . al-Madākhil Ta'lìm al-Lughah al-'Arabiyyah. Makkah: Jāmi'ah Ummu al-Qurā.

Azra, Azyumardi. (2012). Pendidikan Islam: Tradisi Dan dan Modernisasi di Tengah Tantangan Milenium III. Jakarta: Kencana Perdana Media Group.

Chaer, Abdul \& Agustina, Leonie. (2004). Sosiolinguistik. Jakarta: Rieneke Cipta.

Hamid, Abdullah. (2017). Pendidikan Karakter Berbasis Pesantren: Pelajar dan Santri dalam Era IT \& Cyber Culture. Surabaya: Imtiyaz.

Irawati, Indra Ratna. (2016). Stratifikasi dan Mobilitas Sosial. Jakarta: Pustaka Obor Indonesia.

Izzan, Ahmad. (2004). Metodologi Pembelajaran Bahasa Arab. Bandung: Humaniora, 2004.

J.D.Parera. (2007). Morfologi Bahasa. Jakarta: Gramedia Pustaka Utama.

Kushartanti, dkk. (2005). Pesona Bahasa: Langkah Awal MemahamiLinguistik. Jakarta: Gramedia Pustaka Utama.

Lase, Apolonius. (2011). Kamus LI NIHA Nias-Indonesia. Jakarta: Buku Kompas.

Mujib, Fathul. (2010). Rekonstruksi Pendidikan Bahasa Arab dari Pendekatan Konvensional ke Integratif Humanis. Yogyakarta: Pedajogja.

Poedjosoedarmo, Soepomo. (2001). Filsafat Bahasa. Surakarta: Muhammadiyah University Press.

Pranowo. (2016). Teori Belajar Bahasa. Yogyakarta: Pustaka Pelajar.

Putu Wijana \& M. Rohmadi. (2013). Sosiolinguistik: Kajian Teori dan Analisis. Yogyakarta: Pustaka Pelajar.

Rahardi, Kunjana. (2006). Dimensi-dimensi Kebahasaan. Jakarta: Penerbit Erlangga.

Rofiq A, dkk. (2005). Pemberdayaan Pesantren: Menuju Kemandirian dan Profesionalisme Santri dengan Metode Daurah Kebudayaan. Yogyakarta: LKiS. 
Rusman, dkk. (2012). Pembelajaran Berbasis Teknologi Informasi dan Komunikasi Mengembangkan Profesionalitas Guru. Jakarta: PT. Raja Gravimdo Persada.

Sumarsono. (2017). Sosiolinguistik. Yogyakarta: Pustaka Pelajar.

Suwandi, Sarwiji. (2008). Serbalinguistik: Mengupas Pelbagai Praktik

Berbahasa. Surakarta: UNS Press.

Waridah, Ernawati. (2006). EYD \& Seputar Kebahasaan Indonesia. Jakarta:

Kawan Pustaka.

Yusuf, Tayar. (1995). Metodologi Pengajaran Agama \& Budaya. Jakarta:

PT. Rajagravindo Persada.

Zainuddin, Radliyah. (2005). Metodologi \& Strategi Alternatif Pembelajaran Bahasa Arab. Yogyakarta: Pustaka Rihlah Group. 
